\title{
ELEMENTOS DECISIVOS NA CONSTRUÇÃO DA POSIÇÃO E PRÁTICA POLÍTICA DE ROBERTO REQUIÃO DE MELLO E SILVA, de Daiane Carnelos Resende ${ }^{1}$
}

\author{
Maria Julieta Weber Cordova ${ }^{2}$
}

- Enviado em 29/01/2016

- Aprovado em 24/03/2016

Em Ciência e Política: duas vocações, Max Weber pontua que "A política é um esforço tenaz e energético para atravessar grossas vigas de madeira”. Nesse sentido, para Weber, a política se faz, indiscutivelmente, com o cérebro, mas não exclusivamente. E as características essenciais daqueles que são detentores de vocação política perpassam pela tomada de partido, luta e paixão, mas também pelo senso de proporções. A partir de tais argumentações conceituais iniciais, pode-se compreender que as pesquisas que se atêm à trajetória dos atores políticos, constituem-se numa contribuição fundamental às complexas problemáticas que circunscrevem o estudo da vocação política.

A pesquisa de Daiane Carnelos Resende preenche, certamente, uma lacuna no estudo da política local e regional, ao tratar com maestria os Elementos decisivos na construção da posição $e$ prática política de Roberto Requião de Mello e Silva. O estudo contempla a análise da trajetória política de Roberto Requião no período de 1982 a 2006, a partir da formação da posição, da prática política e de seus traços genealógicos, tendo como elementos centrais de análise o Estado, o poder e a ação política.

\footnotetext{
${ }^{1}$ Dissertação de autoria de Daiane Carnelos Resende, defendida no Programa de Pós-Graduação em Sociologia da UFPR, em 2007, sob orientação do Prof. Dr. Ricardo Costa de Oliveira. Versão completa disponível na Biblioteca Digital da UFPR - http://www.pgsocio.ufpr.br/docs/defesa/dissertacoes/2007/daiane.pdf

${ }^{2}$ Universidade Estadual de Ponta Grossa. E-mail: julieta.weber@yahoo.com.br.
} 
Utilizando-se do método qualitativo, a autora realiza um estudo de cunho documental e bibliográfico, subdividindo o texto em quatro grandes eixos de análise, assim denominados: Perspectivas teórico-históricas para a construção de uma trajetória política, Traços decisivos para a formação da posição e ação política, Trajetória política e, por fim, disserta sobre as Políticas públicas e análise de um perfil econômico.

Os instrumentos teóricos para a compreensão conceitual de campo intelectual e de trajetória apóiam-se, fundamentalmente, em Pierre Bourdieu. O recorte da análise direciona-se, num primeiro momento para as Perspectivas teórico-históricas para a construção de uma trajetória política. Assim, ao discutir sobre os Instrumentos políticos para a compreensão de uma trajetória política, a autora discorre sobre os conceitos bourdieusianos de habitus, campo e capitais simbólicos.

No decorrer do trabalho, também são referenciados Maurice Duverger, Harold Lasswell, Nicos Poulantzas e Max Weber, especialmente quando são tratados os conceitos de liderança, autoridade e poder político. Robert Alan Dahl e Guilhermo O’Donnell alicerçam o estudo sobre o contexto histórico político, bem como as pesquisas de Milton Ivan Heller, Marionilde Dias Brepohl de Magalhães e Maria Tarcisa Silva Bega, no que se refere ao contexto histórico do PMDB no Paraná. Francisco Negrão e Ricardo Costa de Oliveira fundamentam a análise dos traços genealógicos.

Ao abordar os Traços decisivos para a formação da posição e ação política de Roberto Requião de Mello e Silva, apreendem-se os Traços genealógicos das famílias Mello e Silva, e Requião, bem como os Traços biográficos de Roberto Requião. Nessa direção, os dados de pesquisa revelam que tanto a família Requião como os Mello e Silva, origina-se da região Nordeste do Brasil. No Paraná, a família Requião, desde Euclides Requião, destaca-se no ramo comercial. Os Mello e Silva destacam-se no campo da política local, bem como no campo intelectual. Justiniano de Mello e Silva, o primeiro nome da família, foi doutor em Ciências Sociais pela Universidade de Córdoba, exerceu alguns mandatos frente à Assembleia Legislativa; seu filho, o Coronel Wallace de Mello e Silva, foi camarista em Curitiba e deputado estadual; seu neto Wallace Thadeu de Mello e Silva foi indicado para prefeito de Curitiba e exonerado meses depois. Em disputa para a prefeitura de Curitiba, perdeu a eleição para Ney Braga.

A disputa política de Wallace Thadeu representou um grande marco na trajetória política de Roberto Requião, que, ainda menino, acompanhou a candidatura de seu pai, momento, inclusive, de seu primeiro discurso em carro aberto em favor de sua candidatura. O estudo aponta, portanto, para uma acumulação de capitais na esfera política, cultural e econômica na trajetória de Roberto 
Requião, e que se fortalece a partir de sua entrada efetiva na vida política, com 41 anos, como deputado estadual, no contexto da redemocratização brasileira.

A pesquisa revela também a participação de Roberto Requião enquanto líder ativo em várias manifestações contra o regime militar no Brasil, em que se utiliza na investigação um documento ímpar, cuja cópia encontra-se anexada ao trabalho em questão. Trata-se do dossiê de Roberto Requião registrado na Delegacia de Ordem Política e Social - DOPS, no ano de 1967, quando estudante de Direito na Universidade Federal do Paraná, identificando-o como "elemento nitidamente esquerdista", "líder" em passeatas estudantis e "assíduo freqüentador das reuniões extremistas do Diretório Central de Estudantes", apresentando, portanto, comportamento considerado nocivo para a manutenção da ordem ditatorial instituída.

Ao trazer para a análise alguns fragmentos de Discurso e Imagem na trajetória de Roberto Requião, aponta-se para alguns dos clichês utilizados em seus discursos, evidenciando atos de fala, dentre os quais se destaquem: "MDB velho de Guerra", "Sou o intelectual orgânico das classes populares", "Opção preferencial pelos pobres", "Me considero um existencialista sartreano de esquerda"; "Meu governo é de esquerda". Tais evidências discursivas são reveladoras daquilo que Habermas conceitua pela teoria da ação comunicativa enquanto diferenciais entre a lógica do discurso teórico e do discurso prático. A autora ainda apreende, a partir de tais falas, as possibilidades de análise imagética e sua relação com a mídia na construção de imagens para utilização no cenário político paranaense.

A abordagem sobre a Trajetória política de Roberto Requião de Mello e Silva perpassa pelas gestões de Deputado Estadual (1982), Prefeito de Curitiba (1986-1989), Secretário de Desenvolvimento Urbano do Paraná (1989-1990), Primeiro Mandato no Governo do Paraná (19911994), Senador da República (1994-2002), Segundo Mandato no Governo do Paraná (2003-2006). Para o Terceiro Mandato no Governo do Paraná, são apresentadas algumas considerações, tendo em conta que o momento da finalização da pesquisa coincide com o início do referido período. Entretanto, a autora aponta para alguns conflitos que já estariam demarcando este último mandato, tanto no que concerne às relações com a mídia, como no que se refere aos embates com o Judiciário e o Ministério Público, além do enfrentamento às acusações de nepotismo.

O último eixo de estudo centra-se nas Políticas públicas e análise de um perfil econômico. Para tal intento, relacionam-se os Traços do federalismo no Brasil e o Contexto teórico sobre descentralização do Estado e desigualdades sociais. Em seguida, investiga as Características 
social-democratas nas políticas requianistas, contextualizando sobre os elementos dessa política econômica, no que intitula por Políticas requianistas e o welfare state paranense.

$\mathrm{Na}$ análise das políticas públicas implantadas por Requião, identifica-se um "perfil requianista", aproximando-o das características de um gestor social-democrata por priorizar a descentralização econômica, tendo como foco de ação a estatização. Destacam-se, assim, dentre os principais programas voltados à área social, a política de manutenção de estatais nas mãos do Estado, instrumentalizando a garantia de necessidades básicas à população, bem como incentivando a valorização da vida no campo por meio de programas como 'Força Rural' e 'Panela Cheia'. Ainda que centralizador no tocante à questão da autoridade, a pesquisa acaba por identificar coerências no tocante aos discursos proferidos por Roberto Requião em sua prática política, demarcando um estilo requianista de governar. 